\title{
Use of the polymerase chain reaction to detect Toxoplasma gondii in human blood samples
}

\author{
D O Ho-Yen, A W L Joss, A H Balfour, E T M Smyth, D Baird, J M W Chatterton
}

\begin{abstract}
Aims: To assess the value of detecting Toxoplasma gondii in human blood samples using the polymerase chain reaction (PCR).

Methods: Blood samples in lithium heparin were examined from 34 patients with suspected toxoplasmosis, and six healthy volunteers with or without the addition of doubling dilutions of toxoplasma tachyzoites. Products of a nested PCR, using oligonucleotide primers of the $B 1$ gene, were analysed by electrophoresis and stained by ethidium bromide. The primary product was 194 base pairs in length; the nested products were 160 or 97 base pairs.
\end{abstract}

Results: When toxoplasma tachyzoites were added to the leucocytes of six different volunteers, eight to 16 parasites were detected by nested PCR in one experiment and one to four parasites in eight experiments. All nine experiments were negative in samples without added tachyzoites. Of 34 patients, PCR was negative in 13 with recent lymphadenopathy; nine with persisting IgM, including two pregnant patients; four with reactivated infection due to immunodeficiency; and five with no evidence of active infection. Positive PCR results were found in three patients with reactivated infection. There was only one discrepancy between PCR and animal culture results; this was in an immunocompromised patient with a positive PCR and negative culture.

Conclusions: The PCR technique was rapid, sensitive, and specific in human blood samples. Negative PCR results in patients with persisting IgM suggested that the fetus was not at risk, or that treatment was not indicated in myalgic encephalomyelitis-like illness. PCR results in immunocompromised patients permitted appropriate management-no treatment if negative, treatment if positive.

$(\mathfrak{F}$ Clin Pathol 1992;45:910-913)

The polymerase chain reaction (PCR) has the potential to change radically the approach to diagnosis in clinical microbiology. ${ }^{1}$ In a study of a PCR directed at the B1 gene of Toxoplasma gondii ${ }^{2}$ there was evidence that trace amounts of parasite DNA could be detected in infected cerebrospinal fluid samples. The technique was reproducible for a different gene (P30) and able to detect infection in animals. ${ }^{3}$ These findings created some optimism that PCR could be a rapid, sensitive technique for diagnosing toxoplasmosis in the immunocompromised and those with congenital infection. ${ }^{4}$

One diagnostic problem is that toxoplasma specific IgM may occasionally persist for several years. ${ }^{5}$ Infection in women before conception does not usually put the fetus at risk, but persisting IgM can make it difficult to identify the time of infection in some women presenting at an antenatal clinic. Toxoplasmosis may also produce a myalgic encephalomyelitis-like illness ${ }^{4}$ and in some of these individuals toxoplasma specific IgM may persist and treatment be considered. In patients with persisting toxoplasma $\operatorname{IgM}$, the PCR result may aid correct management.

Although the initial PCR technique has now been extensively modified and developed, there are still pitfalls ${ }^{1}$ associated with PCR which must be avoided. One difficulty is that while a blood sample is a very convenient sample for investigating human infection, the procedures for using PCR on blood are not fully established. ${ }^{367}$

\section{Methods}

Leucocytes from six healthy volunteers were tested with or without the addition of doubling dilutions of toxoplasma tachyzoites. RH strain tachyzoites were produced in cotton rat peritoneal culture, washed three times with isotonic saline and diluted to the appropriate concentrations in distilled water. Blood samples from 34 patients referred to the Scottish Toxoplasma Reference Laboratory with suspected toxoplasmosis were also examined. Patient blood samples in lithium heparin $(5-20 \mathrm{ml})$ usually arrived within one day of collection and most were processed in this laboratory. The leucocyte fraction was separated by centrifugation on Histopaque (Sigma Chemical Co, Poole) at $1250 \mathrm{~g} / 12.5$ minutes and washed three times in sterile phosphate buffered saline, $\mathrm{pH} 7 \cdot 4{ }^{8}$ The final pellets were resuspended in water and stored at $-70^{\circ} \mathrm{C}$ until tested. In the case of the patient specimens half the final pellet was resuspended in saline for inoculation into two mice.

Sera from 32 of the 34 patients in the study were examined by inhouse IgG and IgM enzyme linked immunosorbent assay (ELISA) $)^{910}$ and by dye test $^{11}$ in the Toxoplasma Reference Laboratory, Raigmore Hospital, Inverness. Specific IgM results were
Correspondence to: Dr D O Ho-Yen Accepted for publication 6 April 1992 
confirmed using a commercially available capture ELISA, Toxonostika IgM (Organon Teknika, the Netherlands). In two patients serology was performed in the Leeds Reference Laboratory using the dye test and the Public Health Laboratory Service IgM. ${ }^{12}$ IgM results above the cutoff were recorded as positive $(+)$ and those within $10 \%$ of the cutoff were recorded as borderline $( \pm)$.

The PCR was directed at the sequence of the B1 gene described by Burg et al. ${ }^{2}$ Oligonucleotide primers S114, S115, P456 and S331, equivalent to their oligos $1,4,2$ and 3 , respectively, were synthesised by Severn Biotech, Kidderminster. The external primers, S114 and $S 115$, correspond to the 5'-ends of the two complementary strands of the sequence; the others are internal, and P456 is 5'-labelled with biotin instead of the T7 RNA polymerase promoter sequence. The complete procedure was a two-stage primary and nested PCR on boiled water extracts of leucocyte fractions, as described before. ${ }^{8}$

Briefly, samples were first boiled for 20 minutes in $0.5 \mathrm{ml}$ conical Treff microtubes (Scotlab, Aberdeen). To $20 \mu \mathrm{l}$ of sample, $30 \mu \mathrm{l}$ of a reagent mix was added and overlaid with $100 \mu \mathrm{l}$ of mineral oil. The mix was made from stock solutions of buffer $(10 \times$ concentrate: $100 \mathrm{mM}$ TRIS-hydrochloride; $50 \mathrm{mM}$ potassium chloride; $25 \mathrm{mM}$ magnesium chloride; $0 \cdot 1 \%$ gelatine $\mathrm{pH} 8 \cdot 3$ ); deoxynucleoside triphosphates (dNTP; $40 \mathrm{mM}$ equimolar dATP, dCTP, dGTP, dTTP; Pharmacia, Milton Keynes); primer S114; primer S115; TAQ polymerase ( 5 units/ $\mu \mathrm{l}$; ILS Ltd, London or Promega, Southampton); and water, respectively, in the ratio $65: 13: 6 \cdot 5: 10: 1 \cdot 8: 295$. Triton $\mathrm{X}-100(0.1 \%)$ was included in the final mix, either by addition to the test sample or the 10 $\times$ buffer concentrate. The PCR procedure involved 30 temperature cycles of $94^{\circ} \mathrm{C} / 1 \cdot 3$ minutes, $53^{\circ} \mathrm{C} / 2$ minutes, $72^{\circ} \mathrm{C} / 2.5$ minutes in a Techne PHC1 Programmable Dri-block (Scotlab, Aberdeen), followed by an extension incubation at $72^{\circ} \mathrm{C} /$ five minutes.

For the nested PCR, the product of the primary PCR was diluted 1 in 200 in water. The $50 \mu \mathrm{l}$ sample volume contained $20 \mu 1$ diluted primary PCR product plus $30 \mu \mathrm{lmix}$ of the following: water $/ 10 \times$ buffer concentrate/ dNTP (40 mM)/internal primer(S331)/either internal (P456) or external (S114) primer/ TAQ polymerase, respectively, in the ratio
612:130:13:10:10:1·8. As long as at least one internal primer is used, the result confirms the specificity of the primary PCR product, as non-specific primary PCR products of about 194 base pairs (which were occasionally seen in some human samples) are unlikely to contain the same sequence as the internal primer. The use of two internal primers yields an even more specific result. One of the primers, P456, was biotin labelled and so could have been potentially detectable by even more sensitive biotinavidin enzyme amplification techniques.

All PCR products were analysed by electrophoresis on $2.5 \%$ agarose (Biorad Labs, Watford) at $133 \mathrm{~V} / 30-60$ minutes. They were identified by staining with ethidium bromide $(1 \mu \mathrm{g} / \mathrm{ml})$ in the electrophoresis buffer (0.089M TRIS-borate; $0.0025 \mathrm{M}$ ethylenediamine tetraacetic acid, $\mathrm{pH} 8 \cdot 3$ ), and their sizes compared with a 123 base pair molecular weight marker ladder (Gibco BRL, Paisley). The primary product was 194 base pairs in length whereas the nested products were either 160 or 97 base pairs, depending on the primers used.

\section{Results}

When dilution series of $10^{5}, 10^{4}, 10^{3}, 10^{2}, 64$, $32,16,8,4,2,1$ and $\mathrm{O} R \mathrm{RH}$ tachyzoites were tested in the presence of $10^{5}$ human leucocytes from six different volunteers, eight to 16 parasites were detected by nested PCR in one experiment and one to four parasites in eight experiments. In all nine experiments nested PCR results were negative when toxoplasma tachyzoites were not added.

Blood samples were received from 34 patients in Scotland, Northern Ireland, and northern England. There were: 13 patients with evidence of current or recent infection (dye test of more than $125 \mathrm{IU}, \mathrm{IgM}$ positive, recent symptoms); nine with persisting IgM, including two pregnant patients; seven with reactivated infection due to immunodeficiency (dye test positive, clinical or other evidence of toxoplasmosis, response to treatment); and five with no evidence of active infection (two past, dye test of less than $125 \mathrm{IU}, \mathrm{IgM}$ negative and three susceptible, dye test less than 8 IU)), but in whom active infection was suspected at time of sampling. The results of routine serology, culture, and PCR on all the patients are presented in table 1. Positive PCR results were

Table 1 Resu1ts of animal culture and PCR on human blood

\begin{tabular}{|c|c|c|c|c|c|c|c|c|}
\hline \multirow{3}{*}{$\begin{array}{l}\text { Infection } \\
\text { type }\end{array}$} & \multirow[b]{3}{*}{ Condition } & \multirow{3}{*}{$\begin{array}{l}\text { Onset } \\
(m)\end{array}$} & \multirow{3}{*}{$\begin{array}{l}\text { No of } \\
\text { patients } \\
(n=34)\end{array}$} & \multicolumn{5}{|l|}{ No positive } \\
\hline & & & & \multicolumn{3}{|l|}{ Serology } & \multirow[b]{2}{*}{ Culture } & \multirow[b]{2}{*}{$P C R$} \\
\hline & & & & $D T>125 I U$ & IgM+ & $I g M \pm$ & & \\
\hline 1 & lymphadenopathy & $1-7$ & 13 & 13 & 11 & 2 & 0 & 0 \\
\hline \multirow[t]{2}{*}{2} & persistent fatigue & $1-30$ & 7 & 4 & 5 & 2 & 0 & 0 \\
\hline & pregnant & - & 2 & 0 & 2 & 0 & 0 & 0 \\
\hline \multirow[t]{3}{*}{3} & malignancy & $1-3$ & 4 & 0 & 1 & 2 & 2 & 2 \\
\hline & HIV & $1-6$ & 2 & 1 & 0 & 1 & 0 & 1 \\
\hline & post-splenectomy & 4 & 1 & 1 & 0 & 0 & 0 & 0 \\
\hline \multirow[t]{2}{*}{4} & pyrexia & 1 & 1 & 0 & 0 & 0 & 0 & 0 \\
\hline & pre-transplant & - & 1 & 0 & 0 & 0 & 0 & 0 \\
\hline \multirow[t]{2}{*}{5} & HIV & - & 2 & 0 & ND & ND & ND & 0 \\
\hline & malignancy & - & 1 & 0 & ND & ND & 0 & 0 \\
\hline
\end{tabular}

$1=$ current or recent infection; 2 = persistent; 3 = reactivated; 4 = past infection; $5=$ susceptible; ND = not tested. 
Table 2 Results of animal culture and PCR on patients studied in more detail

\begin{tabular}{|c|c|c|c|c|c|c|}
\hline \multirow[b]{2}{*}{ Case No } & \multirow{2}{*}{$\begin{array}{l}\text { Infection } \\
\text { type }\end{array}$} & \multirow[b]{2}{*}{ Condition } & \multirow[b]{2}{*}{ Specimen } & \multicolumn{3}{|c|}{ Evidence of active infection } \\
\hline & & & & Serology $y^{\star}$ & Culture & $P C R$ \\
\hline 1 & 4 & Pregnant & $\begin{array}{l}\mathrm{AF} \\
\mathrm{FB} \\
\mathrm{B}\end{array}$ & $\begin{array}{l}- \\
-\end{array}$ & $\begin{array}{l}\overline{\mathrm{ND}} \\
\overline{-}\end{array}$ & $\begin{array}{l}- \\
\overline{N D}\end{array}$ \\
\hline 2 & 2 & Pregnant & $\begin{array}{l}\text { CB } \\
\text { B }\end{array}$ & $\bar{t}$ & $\begin{array}{l}- \\
-\end{array}$ & $\begin{array}{l}- \\
-\end{array}$ \\
\hline 3 & 5 & Cerebral abcess & $\begin{array}{l}\text { BB } \\
\text { B }\end{array}$ & ND & $\overline{\mathrm{ND}}$ & $\overline{\mathrm{ND}}$ \\
\hline 4 & 5 & Pituitary tumour & $\begin{array}{l}\text { BB } \\
\text { B }\end{array}$ & $\begin{array}{c}\text { ND } \\
-\end{array}$ & $\overline{-}$ & $\begin{array}{l}- \\
-\end{array}$ \\
\hline 5 & 3 & HIV cerebral abscess & $\begin{array}{l}\text { BB } \\
\text { B }\end{array}$ & $\begin{array}{l}\text { ND } \\
-\end{array}$ & $\begin{array}{l}\text { ND } \\
-\end{array}$ & $\begin{array}{l}+ \\
+\end{array}$ \\
\hline $\begin{array}{l}6 \\
7\end{array}$ & $\begin{array}{l}5 \\
2\end{array}$ & $\begin{array}{l}\text { HIV dementia } \\
\text { Persisting symptoms }\end{array}$ & $\begin{array}{l}\text { C } \\
\text { C } \\
\text { B }\end{array}$ & $\begin{array}{c}\overline{N D} \\
\pm\end{array}$ & $\begin{array}{l}\text { ND } \\
\text { ND } \\
-\end{array}$ & $\begin{array}{l}- \\
\overline{-}\end{array}$ \\
\hline
\end{tabular}

Infection type as table 1, positive result (+), negative result ( - ). AF allantoic fluid; FB fetal blood; CB cord blood; BB brain biopsy; C cerebrospinal fluid; B adult peripheral blood.

* DT > $125 \mathrm{IU} / \mathrm{ml}$ or specific IgM positive.

only found in three of the seven with reactivated infection (dye test $=30 \mathrm{IU}, 30 \mathrm{IU}$, and $125 \mathrm{IU})$. In two cases animal culture was also positive; in the other, animal culture was negative but a brain biopsy specimen was positive by the PCR (table 2), as well as by immunofluorescence and peroxidase antiperoxidase staining. Seven patients from whom samples other than blood were tested (table 2) were studied in more detail.

\section{Discussion}

The specificity of our nested PCR technique has been shown before and the sensitivity has been shown to be comparable with that of traditional animal culture. ${ }^{8}$ Previous workers have shown that the PCR technique can remain specific in the presence of human deoxyribonucleic acid (DNA). ${ }^{3}$ In most of our dilution experiments in human leucocytes (eight of nine) we were able to detect the equivalent of one to four parasites per sample. The leucocyte concentration used $\left(10^{5} / 20 \mu \mathrm{l}\right.$ sample) is equivalent to $5 \times 10^{9} / 1$ which is within the normal range for a human blood sample. However, the clinical samples were concentrated before testing, by 30-170-fold, to 60-80 $\mu$ l (three to four PCR samples) from a starting volume of $2 \cdot 5-10 \mathrm{ml}$. The average yield from $10 \mathrm{ml}$ of volunteer blood was $1 \cdot 27$ $\times 10^{7}$ leucocytes (range $0.56-2.4 \times 10^{7}$ ), so PCR samples might contain $3.5 \times 10^{5}-8.0 \times$ $10^{6}$ leucocytes. Our experience with animal blood suggests that the detection limit at the upper end of this leucocyte range would be about six parasites. ${ }^{8}$ Thus our method can be used on human blood samples with confidence.

It was disappointing not to detect toxoplasma DNA in any of 13 recently infected individuals. However, these all had lymphadenopathy which had been ongoing for at least five weeks (and more than three months in six cases) before sampling. This suggests that in acute, acquired infections in healthy individuals there is only a transient parasitaemia. The animal culture experiments support this conclusion.

None of nine patients with persisting IgM antibody had detectable toxoplasma DNA in blood. Seven of these had persisting fatigue or muscle weakness, which in three cases were similar to a myalgic encephalomyelitis-like illness. Toxoplasma infection may produce a myalgic encephalomyelitis-like illness. ${ }^{4}$ If toxoplasma specific IgM persists clinicians are tempted to treat the chronic fatigue with antitoxoplasma treatment. The demonstration of a positive PCR result may be a better indicator of the need for such potentially toxic treatment. The negative PCR results indicate that persisting parasitaemia is not the reason for continuing symptoms, but more extensive studies are required to confirm this conclusion. In one patient (case 7 , table 2 ) cerebrospinal fluid taken to test for evidence of multiple sclerosis was also PCR negative. From the negative PCR results in one of the two pregnant women in the group, it was concluded that she was unlikely to transmit infection to her fetus. Subsequent tests at birth on the cord blood (case 2, table 2) showed no evidence of infection and the baby was apparently healthy. The other was tested after spontaneous abortion had occurred but there was no PCR evidence to implicate toxoplasma infection.

Reactivated infection may occur in immunocompromised patients, including those with HIV infection ${ }^{13}$ or malignancy. ${ }^{14}$ As such infection is usually not associated with the production of toxoplasma specific $\operatorname{IgM}^{+13}$ diagnosis may be difficult in these patients. The finding that two of four patients with malignancy (both of whom had recent bone marrow transplants) and one of two HIV positive patients with reactivated toxoplasmosis had detectable toxoplasma DNA in blood represents a significant advance in diagnosis for this type of infection. One patient with malignancy had had immunosuppressive treatment for some time, and consequently may have had prolonged parasitaemia. The HIV patient (case 5 , table 2) had cerebral toxoplasmosis initially diagnosed by a brain biopsy specimen, but it is now evident that diagnosis could have been made by less invasive means. His serological results were unhelpful - a low dye test titre and no specific IgM. Cerebral toxoplasmosis has been reported in a patient who had no serological evidence of previous and therefore latent toxoplasmosis. ${ }^{15}$ In these circumstances 
PCR, perhaps on blood specimens, may assist diagnosis. A test which allows a faster and easier diagnosis to be made may help patients gain the benefits of earlier anti-toxoplasma treatment, and negative results are an indicator to withhold anti-toxoplasma treatment.

This study has shown that the PCR can be reliably used on human blood samples. For a reference laboratory, this is a valuable addition to its array of diagnostic tests, and provides a more rapid assay than animal culture. In patients with acute acquired infection parasitaemia may have been detectable in earlier specimens. However, in this group of patients diagnosis is achieved by routine serological tests and treatment is not normally necessary. A major finding in the current study was that three of seven patients with reactivated infection, for whom routine serological tests were inadequate, gave positive results by the PCR on blood. In one case the PCR result was not confirmed by animal culture, but as positive PCR and histological results were found in a brain biopsy specimen from the same patient, the discrepancy suggests that the PCR is more sensitive than culture. We believe that our results in experimental animals ${ }^{8}$ and our current findings suggest that parasitaemia equates with current, active infection. The new PCR technique has provided an insight into the pathophysiology of toxoplasma infection, as well as providing an indicator for active treatment.

We are grateful to the Scottish Home and Health Department for grant K/MRS/50/C 1429 , and to those who have willingly sent us samples and to Ms V MacFarquhar for secretarial assistance.

1 Hayden JD, Ho SA, Hawkey PM, Taylor GR and Quirke P. The promises and pitfalls of PCR. Rev Med Microbiol 1991;2:129-37.

2 Burg JL, Grover CM, Pouletty P, Boothroyd JC. Direct and sensitive detection of a pathogenic protozoan, Toxosensitive detection of a pathogenic protozoan, Toxo-
plasma gondii, by polymerase chain reaction. I Clin plasma gondii, by polymeras

3 Savva D, Morris JC, Johnson JD, Holliman RE. Polymerase chain reaction for detection of Toxoplasma gondii. $\mathcal{f} \mathrm{Med}$ Microbiol 1990;32:25-31.

4 Ho-Yen DO. Toxoplasmosis in humans. $f$ Roy Soc Med 1990; 83:571-2.

5 Skinner LJ, Chatterton JMW, Joss AWL, Moir IL, Ho-Yen DO. The use of an IgM immunosorbent agglutination assay to diagnose congenital toxoplasmosis. $\mathcal{f}$ Med Microbiol 1989;28:125-8.

6 van de Ven E, Melchers W, Galama J, Camps W, Meuwissen $\mathrm{J}$. Identification of Toxoplasma gondii infections by $\mathrm{B}$ gene amplification. $f$ Clin Microbiol 1991;29:2120-4

7 Weiss LN, Udem SA, Salgo M, Tanowitz HB, Wittner M Weiss LN, Udem SA, Salgo $M$, Tanowitz HB, Wittner $M$.
Sensitive and specific detection of toxoplasma DNA in an experimental murine model: use of Toxoplasma gondiispecific cDNA and the Polymerase Cain Reaction. $F$ Infect Dis 1991;163:180-6.

8 Joss AWL Chatterton JMW, Evans RE, Ho-Yen DO. Toxoplasma polymerase chain reaction on experimental blood samples. $\mathcal{F}$ Med Microbiol (in press).

9 Joss AWL, Skinner LJ, Chatterton JMW, Chisholm SM Williams $\mathrm{H}$, Ho-Yen DO. Simultaneous serological screening for congenital cytomegalovirus and toxoplasm infection. Public Health 1988;102:407-17.

10 Joss AWL, Skinner LJ, Moir IL, Chatterton JMW, Williams $\mathrm{H}$, Ho-Yen DO. Biotin-labelled antigen screening test for H, Ho-Yen DO. Biotin-labelled antigen screening test for
toxoplasma IgM antibody. $\mathcal{f}$ Clin Pathol 1989;42:206-9.

11 Joss AWL, Skinner LJ, Chatterton JMW, Cubie HA, Pryde JFD, Campbell JD. Toxoplasmosis: effectiveness of enzyme immunoassay screening. Med Lab Sci 1989;46: 107-12.

12 Payne RA, Joynson DHM, Balfour AH, et al. Public Health Laboratory Service enzyme linked immunosorbent assay for detecting Toxoplasma specific IgM antibody. 7 Clin Pathol 1987;40:276-81.

13 Holliman RE. Toxoplasmosis and the acquired immune deficiency syndrome. $\mathcal{F}$ Infect 1988;16:121-8.

14 Ruskin J, Remington JS. Toxoplasmosis in the compromised host. Ann Intern Med 1976;84:193-9.

15 Suzuki Y, Israelski DM, Dannemann BR, Stepick-Biek P, Thulliez P, Remington JS. Diagnosis of toxoplasmic encephalitis in patients with acquired immunodeficiency syndrome by using a new serologic method. I Clin syndrome by using a new
Microbiol $1988 ; 26: 2541-3$. 